\title{
Economic Perspectives of Trademarks
}

\author{
Rishi Ram Chapagai ${ }^{1}$
}

\begin{abstract}
Primarily, this paper examines the role of trademark in global economy, as an intellectual property the value of trademark and brand in the global marketplace, and the economic potentiality of trademarks to generate more value and surplus in the economy. This paper also discusses the contribution of the trademarks for creating brand and value of business enterprises. The article is basically conceptual and descriptive in nature. Based on the literature review, the purposes of this paper are; to assess the perceived value of a trademark and brand, to examine the trademark roles for creating brand and value and to understand the impact of trademark on economy.

The article deals with trademark and its economic perspectives. This article is valuable to understand the value of trademark in marketplace. The article helps academicians and practitioner to know the concept of trademark as an intellectual property and to understand that it can be used by market economy to generate more income, value, and surplus in the economy. The economic perspective of trademark can be applicable to many segments of Nepalese business context; ranging from manufacturing to service sector and importantly for the entrepreneurship development. Finally, the article is recommending for further empirical research study to examine the impact of trademark protection system for the countries'economic growth.
\end{abstract}

Keywords: Intellectual Property, Trademark, Value of Trademark, Economy, Marketplace

\section{Introduction}

We can see many goods and services on the global market daily. From the consumer perspectives, we are exposed to hundreds of trademarks and service marks in our everyday life.

Article 15(1) of Trade Related Aspects of Intellectual Property Rights (TRIPS) agreement of World Trade Organization (WTO) defines trademark as any sign, word, phrase, letter, number, sound, smell, shape, logo, picture, or a combination of these which are used to distinguish the product and service among the producers and service providers. Most of the buying decisions of consumer based on the reputation of trademarks and brands. Trademark as an intellectual property, is a very critical element in today's competitive market place and digital market space. Business enterprises are using trademark as a legally protected valuable and important marketing tool for product and service differentiation (Solpe, 2014).

Intellectual Property Rights (IPRs) are the legal rights to protect the creativity of human beings. Mostly, IPRs such as patents, copyright, industrial design and protection of plant varieties encourage creativity and

1 Mr. Chapagai is Faculty Member at Boston International College (affiliated to Pokhara University), Bharatpur, Chitwan, Nepal, Email: rchapagai@gmail.com 
inventiveness for the development of new or improved products and services. On the other hand, IPRs such as Trademark consist of unique sign, word, phrase, letter, number, sound, smell, shape, logo, picture, or a combination of these has economic function to maintain the honesty of the market place by correcting the imbalance between buyers and sellers in the information of a product or service quality and other attributes (Barnes, 2006).

Since the ancient times, trademark is used as commercial and marketing tool for the establishment of competitiveness to promote the market efficiency. Trademark as an intellectual property (IP) is a very critical element in today's competitive marketplace and digital market space. Enterprises are using trademark as a legally protected valuable and important marketing tool for product and service differentiation (Solpe, 2014) . Trademarks are used to support consumers to select a product or service that promises a higher quality with good impression, a good brand, and attractive. A recognized trademark and brand can be most valuable intangible assets of a company. Trademarks create and protect the brands to generate earnings and to differentiate from the competitors. Generally, a 'Trademark' is understood as a 'Brand' (WIPO and KIPO, 2009).

As a registered IP right, trademark came into practice from the 19th century. Trademark as logos and promotional efforts have been using by firms for a long time for the enrichment of the reputation and image of the products. Because of the globalization, liberalization of international trade and the advancement of the digital technology, need of brands, publicity, and trademarks are growing globally. In many middle- and low-income economies countries, we can observe that trademark filings and registration system has been growing rapidly. Today, brands and trademarks are not only use by business sectors. It is also preferred and considered by nations and institutions to build the good image and reputation. Precisely, business enterprises, institutions and nations are conscious and interested to enhance the brands and trademarks value (World Intellectual Property Organization, 2013).

Some trademarks such as Olympic logo and FIFA World Cup logo are used by nations and organizations as global 'cultural icons' which are beyond the business branding. These icons communicate a strong message about their special characteristics. Generally, business enterprises use trademarks as effective marketing tools to communicate a strong and focused message about products, services and cultures. For the effective implementation of business strategies, trademarks are integrated with franchising and licensing strategies to increase the companies' market share and to achieve the financial and strategic objectives (Idris, 2003). Solpe, (2014) states that companies often use trademark or service-mark to differentiate themselves and their products and services from their competitors. Trademark contributes to develop the image and reputation of a business and its products in the eyes of consumers. A positive brand image and reputation of a trademark develops a trust within consumers. Trademark creates the brand loyalty of consumers for the consistent move towards the branded product that is perceived as a higher quality product or services.

\section{Statement of the problem}

In this globalized market economy, branding is a fundamental component and a significant feature of our 
Economic Perspectives of Trademarks

day to day life. There are large amounts of investments by business enterprises for the advertisement of their products and services and building a brand name in the marketplace. Finally, these activities influence consumer buying behaviour for choosing a branded product or services which determines the profitability and value of companies. Eventually, branding shapes the competitiveness of the business organizations with important implications for economic welfare (World Intellectual Property Organization, 2013).

Branding with trademark strategies and how these strategies affect market outcomes is therefore an important subject matter of study. How trademark is playing the role to protect the exclusivity of brands in global market economy is key element of this concept paper.

\section{Objectives of the study}

Primarily, the objective of this study is to examine the role of trademarks in global economy, value of trademark and brand in the global marketplace, and the economic potentiality of trademarks to generate more value and surplus in the economy.

\section{Methodology of the study}

Basically, this article is descriptive in nature and based on literature review. Based on the existing literature and published secondary data, the economic perspectives of trademark is discussed to examine the trademark roles for creating brand and value of the enterprises and to understand the impact of trademark on brand reputation and image, and economic development of the countries.

\section{Intellectual Property and Trademark}

Trademarks are used to support consumers to select a product or service that promises a higher quality with good impression, a good brand, and attractive. A recognized trademark and brand can be most valuable intangible assets of a company. Trademarks create and protect the brands to generate earnings and to differentiate from the competitors. Generally, a 'Trademark' is understood as a 'Brand'. Since the ancient times, trademark is used as commercial and marketing device for the establishment of competitiveness to promote the market efficiency. From a consumer perspective, the value of a brand can be defined by the promise and delivery of quality of product and services offered by a firm. However, from an entrepreneurial perspective, the security of future earnings is the value of a brand (WIPO and KIPO, 2009).

Patent and Trademark both are the Intellectual Property of a company. However, a patent is limited by period but a trademark can be used persistently for long period if the brand is built consistently and properly over time. For example, Aspirin was developed in the beginning of the last century and its patent expired long ago. However, Bayer Company with trademark protection using Aspirin as a reputed brand image for the foreseeable future. The company is still making huge revenues as a result of its strong brand image and value (Solpe, 2014). This indicates that trademark protection allows firms to prevent others from free-riding on investments made in order to build consumer goodwill, and trust which then extends the firms' exclusivity over their brand names. This situation is generally seen in the pharmaceutical industry where the company 
maintains its existing market share of their branded drugs even after the expiry of patent period.

Trademarks as a registered IP right came into practice from the 19th century. For building the reputation and image, brief logos and promotional efforts have been using by business entities for a long time. The dependence on brands, advertising and trademarks of companies are mounting because of the economic globalization, international trade and the growth of digital technology. Trademark filings and registration has been increased rapidly in many middle- and low-income economies. In these days not only the business companies, brands and trademarks are also favored and considered by nations and institutions. Precisely, companies and nations are aware of the value of brands and trademarks (World Intellectual Property Organization, 2013).

\section{Value of Trademark and Brand}

Trademarks integrate the names, terms, signs, symbols, logos and designs for creating typical images of product and services of the companies to generate economic values and benefits. Trademarks are the intangible assets with the capability of generating future revenues, enhancing customers'value propositions, protecting competitive positions, and increasing the attractiveness of business in global business environment. At the present time, brands are created and protected by trademarks. Superior position of companies is strongly supported by trademarks and brands. The value of brand is the monetary compensation which is expected to be received from licensing, franchising or from the sale of that brand (Solpe, 2014).

Branding is an essential and crucial element of this globalized market economy. Business enterprises are investing large amounts of their capital in promoting the product and services for building a brand name in the marketplace. Ultimately, these activities influence consumer buying decision for choosing a branded product or services. Branding is based on the advertisement of the product and services. Investment in branding determines the profitability and brand value of the companies. The competitiveness of the business enterprises in the market is shaped by the trademarks and brands with the implications of economic accomplishment (World Intellectual Property Organization, 2013).

Brand Finance report (2017) reveals that technology based US Company Google (Google Inc.) is in first position with brand value of USD 109,470 Million in Global Brand 2017. The table shows that its brand value has been increased by 24 percent in 2017. The table depicts that the Apple Company has decreased 27 percent value from 2016 and degraded from first position to second position with USD 107,141Million from 145, 918 Million brand value (Brand Finance, 2017). This indicates that the brands and trademarks are the source of competitive advantages and valuable Intellectual Property. According to Brand Finance report 2017, brand is a marketing-related intangible asset which incorporates the names, terms, signs, symbols, logos and designs for creating distinctive images of product and services associated with stakeholders of the companies to generate economic values and benefits. 
Economic Perspectives of Trademarks

Table 1- The most valuable brands, 2017

\begin{tabular}{|c|c|c|c|c|c|c|c|}
\hline Brand Name & Industry Group & Domicile & $\begin{array}{c}\text { Brand Value } \\
2017 \text { (USD } \\
\$ \text { Million) }\end{array}$ & $\begin{array}{c}\text { Brand Value } \\
2016 \text { (USD } \\
\$ \text { Million) }\end{array}$ & \% Change & $\begin{array}{c}\text { Rank } \\
2017\end{array}$ & $\begin{array}{c}\text { Rank } \\
2016\end{array}$ \\
\hline Google & Technology & US & 109,470 & 88,173 & $24 \%$ & 1 & 2 \\
\hline Apple & Technology & US & 107,141 & 145,918 & $-27 \%$ & 2 & 1 \\
\hline Amazon.com & $\begin{array}{c}\text { Technology } \\
\text { Retail }\end{array}$ & US & 106,396 & 69,642 & $53 \%$ & $\mathbf{3}$ & 4 \\
\hline AT\&T & Telecoms & US & 87,016 & 59,904 & $45 \%$ & $\mathbf{4}$ & 6 \\
\hline Microsoft & Technology & US & 76,265 & 67,258 & $13 \%$ & 5 & 4 \\
\hline Samsung & Conglomerate & SOUTH & 66,219 & 58,619 & $13 \%$ & $\mathbf{6}$ & 7 \\
\hline Verizon & Telecoms & US & 65875 & 63,116 & $4 \%$ & $\mathbf{7}$ & 5 \\
\hline Walmart & Retail & US & 62,211 & 53,657 & $\mathbf{1 6} \%$ & 8 & 8 \\
\hline Facebook & Technology & US & 61,998 & 34,002 & $82 \%$ & 9 & 17 \\
\hline ICBC & Banks & China & 47,832 & 36,334 & $32 \%$ & 10 & 13 \\
\hline
\end{tabular}

Source: The annual report on the world's most valuable brands, (Brand Finance, February 2017)

Trademarks and brands are becoming key components in corporate strategy and marketing management with the increasing recognition of its economic value. In recent times, the accumulation of substantial corporate IP assets and IP asset management is one of the corporate strategies of the knowledge and technology based industries. Trademark and brand valuation is very common for the purposes of commercialization, sale and purchase of trademarks. Trademarks and brands valuation commonly apply for the buying or selling a company, licensing, joint ventures, mergers and acquisitions, franchising, and strategic partnership decisions. Some firms are giving the importance of brand valuation for the investment planning, building partnership through cross-licensing with each other to enhance the value of their trademarks, brands and IP assets (Idris, 2003). In the long run, the competitiveness of the business organizations and their economic prosperity is enhanced by their trademarks and brand image (World Intellectual Property Organization, 2013).

\section{Trademarks in the global economy}

Economists believe and explain that knowledge and innovation play a crucial role for the economic growth of the countries. It is generally agreed that the knowledge, innovation, technology transfer, and protection of the IP rights are the key contributing factors for the fast economic growth of some countries (Idris, 2003). Trademarks play a valuable macroeconomic function to identify the origin of the products, services and technologies. Trademarks look after the accountability to the consumers.

Trademarks play an important strategic role in business enterprises for the promotion of the sales of product and service in market. Trademarks help to strengthen the consumer loyalty towards products and services. 
Consumer loyalty helps to enhance retention of customer which is effective as the attraction of new customers for the companies' revenue generation. Trademarks enable firms to increase profitability, respond to unfair competition, grow and retain market share, differentiate products and services, introduce new product and service lines, earn income through royalties of licensing and franchising, support partnerships and strategic alliances, and rationalize the financial value of the firms. Most of the global companies such as KFC, McDonald's, Coca-Cola, and General Motors are using franchising business model to use their trademark strategically all over the World. Franchising business model is very popular for the strategic use of a trademark (Idris, 2003).

\section{Global Trademark applications}

According to WIPO Statistics Database (2015) a total of 33.1 million trademarks were active in 124 IP offices worldwide. WIPO statistics depict that the trade mark application and registration is higher than the patent and other IP assets. By using the application class count, trademark filing activity grew by $6.9 \%$ in 2014. It is recorded after the harmonizing the filing systems of trademark application and registration across national and regional offices. In 2014, total number of classes specified in applications reached 7.45 million which is more than 66 percent increment from the year 2004. From the year 2004 the complete class counts system has been started (World Intellectual Property Organization, 2015).

In 2014, about 5.19 million trademark applications were filed all over the World which is 6.9 percent more than in 2013. This growth was achieved by the radical increment in trademark filings in China. Since 2000, trademark applications have been increased doubled. The double digit growth of trademark application was seen in the year 2010 and 2011. However, around 6- 7 percent application growth rate has been achieved from the year 2012 to 2014. (World Intellectual Property Organization, 2015). Figures indicate that the economic growth of the individual country and the World economy can be the contributing factor for the trademark application and registration.

WIPO facts and figures (2015) suggest that until the mid-1980s, the trademark filings in the world were low and stable. However, most of the countries adopted the economic liberalization and privatization policy since 1990. The adaptation of the market economy resulted that the trademark filings at China, USA, India, Brazil, and South Korea has been increased. China has received the largest trademark applications after the transformations of Chinese economy (World Intellectual Property Organization, 2015).

\section{Trademark applications by Goods and Services}

For the registration of product and service marks, the international 45 Nice Classification system of Goods and Services was established by an agreement concluded at the Nice Diplomatic Conference (June 15, 1957, revised at Stockholm, in 1967, and at Geneva, in 1977) (World Intellectual Property Organization, 2015). In this classification system, the first 34 classes are allocated for goods class and the remaining 11 for the service classes. According to WIPO (2015), nearly 65 percent trademarks were covered by the goods classes 
where 35 percent has been applied from the service classes in 2014 applications all over the World (World Intellectual Property Organization, 2015). Facts indicate the leading nature of goods classes in application and registration of trademarks worldwide.

\section{Trademark shares by income group}

Countries under the high-income group covers the $45.2 \%$ of the world trademark registration where upper middle-income countries group shares $44.4 \%$. The lower-middle income countries share $9.6 \%$ where only $0.8 \%$ is shared by the low-income countries. The World Intellectual Property Indicators (2015) show that the Asia and Europe share the high percent of trademark registration in 2014. However, the Africa and Oceania share the low trademark registration in 2014. Because of the emerging economy of China and India the average growth rate of trademarks application in Asia is 9.5\% which is the highest in 2014 (World Intellectual Property Organization, 2015). This shows that the economic activities and revenues of countries influences the trademark application and registration.

From the observation of WIPO statistics database (2015), it is agreed that China accounts the highest trademark application class count in 2014 . China covers the $30 \%$ of worldwide trademark filing movement. China has 2.22 million class count with highest 18.2\% annual growth in trademark application. The USA reports 471,000 class count with $6.7 \%$ annual growth rate. Japan with $16.9 \%$, and India with $15.4 \%$ annual growth also conveyed the top in trade mark application class count. WIPO statistics illustrate that the top ten IP offices of the world occupied the $63 \%$ of the worldwide trademark filing activity in 2014. (World Intellectual Property Organization, 2015). These statistics also clarify that the economic activities and market economy of the country facilitates the growth of trademark application.

Regarding the trademark application class count per 100 billion USD Gross Domestic Product (GDP) for selected origins, China has the highest USD 12071 contribution per 100 billion USD GDP in 2014. Most of the countries have improved their trademark contribution for economic growth and the GDP from the year 2004 to 2014. Excluding Jordan other origins have enhanced the trademark contribution in the economy (World Intellectual Property Organization, 2015).

WIPO statistics figure shows that the countries of middle and low- income economy such as Viet Nam, Philippines, Colombia, Malaysia, and Pakistan receive substantially higher numbers of trademarks applications than other forms of IP in 2014. It shows that trademark protection system has been emphasized by the middle and low- income countries with their economic growth (World Intellectual Property Organization, 2015). 
Distribution of application class counts in the top three sectors for each top five office, 2014

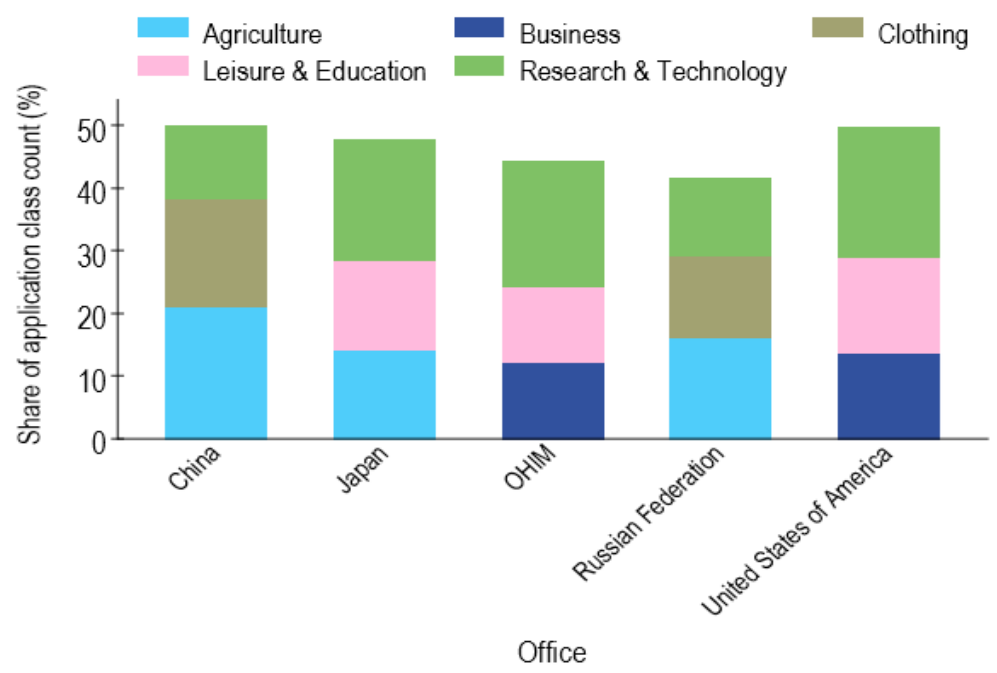

Note: OHIM is the European Union's Office for Harmonization in the Internal Market.

Source: WIPO Statistics Database, October 2015.

WIPO statistics of top five IP offices (2015) depict that China has the highest trademark filings activity in agriculture industry followed by the clothing, and research \& technology industries in 2014 . However, USA has the highest trademark filings in research \& technology industry followed by the leisure \& education, and business industries. Japan and European Union's Office for Harmonization in the Internal Market (OHIM) also have the highest trademark filings activity in research \& technology in 2014. Figures show that leisure \& education, research \& technology, agriculture, clothing, and business sectors are the leading industries in trademark application worldwide. Research and technology industry can be seen as the popular trademark applications sector at every top five IP offices. Leisure and education is the top industry sectors at USA, OHIM and in Japan. China and the Russian have the strong focus of trademark application in the agriculture and clothing industries. The trademark applications activity in goods classes have been dominated by the scientific equipment, fashion and pharmaceuticals industries products. However, trademark registrations for services classes are leading by the business services and education sectors. (World Intellectual Property Organization, 2013). These are the fundamental facets of trademarks in the global economy.

\section{Brands Reputation and Image in the Global Marketplace}

Enterprises based in emerging economies have improved their investment in branding and creating brand value faster than the companies in high income economies. The total value of the top 500 brands of emerging economies is increased by 3 percent from 2009 and 2013. This proves the increasing trends of investment in trademark protection and branding by emerging economy. Globally, companies have invested about USD 466 billion for branding in 2011. WIPO research findings emphasized that the countries' level of economic development and their investment in branding of products and services are closely related. More economic growth means more trademarks application and investment in branding. Emerging economies like China and India are financing immense capital for trademarks and brand building than high-income economies 
Economic Perspectives of Trademarks

countries. For the protection of reputation and brand image, the importance of trademark protection of goods and services is gradually increasing in today's more dispersed and virtual markets. (World Intellectual Property Organization, 2013).

As an intangible asset, trademark accelerates the Brand Equity development mechanism with a brand value of a company in the marketplace. The quality of product or service associated with the brand and the name and recognition of the product and services are the contributing factors for the valuation of brands. A company may have patent and trademark as IP assets in a single product. However, Patent can be expired after limited time period where trademark can go for long period with brand value. In the global marketplace, some companies are still generating revenues as a result of strong brand image protected by trademarks after the expired of the patent of their products. Therefore, trademark protection gives access to companies to stop others from free riding of their investment on trademark, brand and image (Solpe, 2014).

\section{Benefits of Trademarks to society (Consumer Perspective)}

Trademarks help consumer to purchase a product and service of their like with distinct name. If all similar products and services are sold under the same name, consumers may fail to recognize the products and services they liked and which can mislead them to get a product with the quantities and qualities they needs. Trademark protection promotes brand competition, which leads to higher quality products in the marketplace (Hennessey, -----). Generally, it is agreed that consumers spend time and money for researching different offerings before deciding which good or service to purchase. Trademark protection helps consumers to reduce their search costs to get the desired products and services. Trademark protection system and brand empowers consumers to draw on their past experience and to correct information asymmetry about specific goods and services. The trademark protection system and brand provides the legal framework to support consumers' confidence to purchase the product and service as they intended. However, this mechanism only works if consumers are confident. Beside this, trademark system also drives producers and sellers towards creating brief identifiers for specific product or services for the effective communication about products and services (World Intellectual Property Organization, 2013).

\section{Trademark implication in Nepalese context}

Trademark is an important intellectual property which creates brand and value in the global marketplace. The competition on the marketplace can be upraised due to the high investment in branding activities of companies which creates barriers for new entry. Sometimes People condemned the trademarks as creator of monopolies because of restricting the new entry in the marketplace. However,ccompanies build reputation and image by branding and trademarks. Brands and trademark are essential guide for consumers to differentiate the products and services of their choice. Consuming high value brands products and services are perceived as quality, image and status. Brands protected by trademarks enables market economy to operate effectively and efficiently. Consumers have the perceived value of a trademark and brand. For the 
creation of brands and their values, the trademarks play important role in global business environment. The trademark has positive impact on brand reputation and image which facilitates for developing consumers' brand loyalty. Trademarks and brands come with a certain image which is concerned by consumers for the purchase and consumption of product and services. Brands created by trademarks are the source of competitive advantages and valuable intangible assets which ultimately affect the sales, profits, and brand value of the companies. The level of economic development and investments in branding are closely related. Today China and India as rapidly growing emerging economies countries are investing more in trademarks and branding than countries of high-income economies. Importance of trademarks is gradually increasing for the protection of reputation and brand image in today's more dispersed and virtual markets (World Intellectual Property Organization, 2013).

There is a relationship between trademark and economic development of countries. The concept of trademark registration and creating brand value is applicable to many segments of Nepalese business organizations; ranging from manufacturing to service business enterprises. Trademark can help to develop the corporate image, product and service image and brand value of Nepalese business organizations in national and international marketplace. Trademark and brand value has direct applicable to business enterprises to develop the brand image and reputation by formulating trademark strategies to protect the trademarks in domestic and global business competition. For creating the brand image, Nepalese enterprises need to register trademark for avoiding offence from the competitors. It also helps to correct the information asymmetry about specific products and services in the marketplace.

\section{Conclusion and recommendation}

From the above discussion based on secondary source of statistics and existing literature, it can be concluded that trademark is a common marketing tool and strategy for the promotion of brands of product and services. A registered trademark became a key approach of guaranteeing quality and building brands. Trademark can be a vehicle for economic advancement of the countries. Trademarks give economic potential and could be used by market economy to generate more income, value and surplus in the economy. Trademark protection system can play a dynamic role for the smooth economic development of a country. The legal protection of trademarks and brands encourage and support the innovation and creativity in manufacturing and service industries. Trademark protection mechanism is influential in the context of global, regional, national, and enterprise level economic development. Trademark as a significant IP asset creates brand and value in the global marketplace. Reputation and image of the products and services are developed by the trademark protection mechanism. Trademark protection system is the means of the economic growth which enables the product and service trade in the marketplace. It can be the source of competitive advantages and valuable intangible assets of the business enterprises for the future sales, profits, brand value and economic wellbeing of the companies. Trademark protection and brand reputation also benefits the consumer society of the world.

Finally, it is recommended for the further research to examine the impact of trademark protection system 
Economic Perspectives of Trademarks

for the countries' economic growth and GDP with the support of primary data and empirical research study.

\section{Bibliography}

Barnes, D. W. (2006). A New Economics of Trademarks. Northwestern Journal of Technology and Intellectual Property, 5 (1), 22-67.

Brand Finance. (2017, February). The annual report on the world's most valuable brands 2017. Brand Finance Global 5002017 . Retrieved May 10, 2017, from http://brandfinance. com/images/upload/global_500_2017_locked_website.pdf

Hennessey, W. O. (-----). The Role of Trademarks in Economic Development and Competitiveness, FRANKLIN PIERCE LAW CTR,.

Idris, K. (2003). Intellectual Property - A Power Tool for Economic Growth (2nd ed.). Geneva: WIPO (Publication, No. 888e.).

Solpe, V. V. (2014). Managing Intellectual Property (4 ed.). Delhi: PHI Learning .

WIPO and KIPO. (2009). IP Panorama. Geneva: World Intellectual Property Organization .

World Intellectual Property Organization. (2015). IP Facts and Figures. Geneva: WIPO Publication ( No. 943E/15).

World Intellectual Property Organization. (2015). World Intellectual Property Indicators. Geneva: WIPO Publication (No. 941E).

World Intellectual Property Organization. (2013). World Intellectual Property Report: Brands - Reputation and Image in the Global Marketplace. Geneva: WIPO publication. 